\title{
Provisioning patterns and choice of prey in the digger wasp Cerceris arenaria (Hymenoptera: Crabronidae): the role of prey size
}

\author{
Carlo POLIDORI, Roberto BOESI, Francesco ISOLA and Francesco ANDRIETTI
}

Dipartimento di Biologia, Sezione di Zoologia e Citologia, Università degli Studi di Milano, via Celoria 26, 20133 Milano, Italy; e-mail: cpolidori@virgilio.it

Key words. Cerceris arenaria, Hymenoptera, Crabronidae, behaviour, nest provisioning, prey, Curculionidae, hunting specialization

\begin{abstract}
At a nest site in Northern Italy of females of the weevil-hunting digger wasp Cerceris arenaria L. (Hymenoptera: Crabronidae) the provisioning activity and predator-prey relationship were investigated, in particular their specialization in choice of prey. Females were active from middle of June to end of July, and from 8.00 to 19.00. The wasps made provisioning flights throughout the day, mostly in late morning and early afternoon. Individual wasps generally only hunted for 1 or 2 prey species of all those available, maybe because of their higher abundance. The size of prey, which is positively correlated with that of the female wasps, seems to be the main factor determining choice of prey. The nature of the provisioning flights seems to be related to the size of the prey, being more frequent and shorter for smaller weevils. The correlation between prey and wasp biomass is discussed in relation to the size range of the wasps.
\end{abstract}

\section{INTRODUCTION}

Recent studies on sphecoid wasps have focused on predatorprey relationships because of the interest in the possibility of using these predators in biological control (Frank \& Bennet, 1995; Lecoq \& Pierozzi, 1995; Gulmahamad, 1997).

Cerceris wasps dig multicellular nests in the soil, which they provision with Hymenoptera or Coleoptera to feed their larvae. The nests often occur in large aggregations (Evans, 1971; Alcock, 1975; Willmer, 1985; McCorquodale, 1989; Polidori et al., in prep.). In general, a nest is progressive (the older cells are closest to the surface of the soil), but in some species regressive nesting (the older cells are the deepest in the ground) is known (Salbert \& Elliot, 1979; Byron \& Asís, 1997). The females are mass-provisioners and leave the nest entrance open during provisioning flights. Cerceris arenaria L. provisions its nest exclusively with weevils (Curculionidae) and builds progressive nests (Bohart \& Menke, 1976).

The aim of the present study is to describe the daily provisioning patterns and analyse for possible size or taxonomy based preferences in the choice of prey by individual females.

\section{METHODS}

The observed aggregation of $C$. arenaria, of size $13 \times 1.6 \mathrm{~m}$ (average between 1997-99), was situated on a farm located in Castiglione d'Adda (Lodi province, Lombardy). Details of the methods used, the temporal changes in the dimension and nest density of the aggregation, its geography, and vegetation and environmental characteristics of the site are reported elsewhere.

The study was carried out over 4 years during the activity season of the wasps. In particular, the observations made at Castiglione d'Adda were in the periods: $11^{\text {th }}$ June $-25^{\text {th }}$ July in 1997 , $9^{\text {th }}$ June $-24^{\text {th }}$ July in $1998,8^{\text {th }}$ June $-20^{\text {th }}$ July in 1999 and $18^{\text {th }}-19^{\text {th }}$ July in 2001 . The field observations, on the days without rain, lasted from about 8.00 to 19.00 (solar hour time).

187 females were marked in 1997, 178 in 1998, 101 in 1999 and 55 in 2001. Air temperatures were recorded every hour (8.00-19.00) by shaded thermometer, located $10 \mathrm{~cm}$ above the soil.

The approximate size of the prey carried by the wasps to their nest was assessed using the pro-mesothorax junction width as: "small" (about 0.7-1.2 mm), "medium" (1.3-1.9 mm) or "large" prey $(2.0-2.7 \mathrm{~mm})$. The accurately measured wasps and prey came from an area close to the aggregation of nests. While prey were collected during the periods given above provisioning habits were recorded only during the 1997 season.

\section{RESULTS}

\section{Provisioning patterns and associated behaviour}

The females spent most of the time (except at night and on rainy days) out of their nest $(81 \%, \mathrm{n}=1701 \mathrm{~h})$. Most of the time spent out of the nest $(57 \%, \mathrm{n}=1378 \mathrm{~h})$ and largest number of flights $(81 \%, \mathrm{n}=3040)$ were provisioning flights as they returned to their nest with prey. The mean duration of a provisioning flight was $47^{\prime} 39^{\prime \prime}$ (range: $1^{\prime} 40^{\prime \prime}-6 \mathrm{~h} 48^{\prime} 00^{\prime \prime}, \mathrm{SD}=$ $52^{\prime} 37^{\prime \prime}, \mathrm{n}=2211$ ) and median 19'11"; the mean duration of a return flight without prey was $51^{\prime} 20^{\prime \prime}$ (range: $5^{\prime} 00^{\prime \prime}-8 \mathrm{~h} 30^{\prime} 00^{\prime \prime}$, $\mathrm{SD}=46^{\prime} 18^{\prime \prime}, \mathrm{n}=474$ ) and the median $39^{\prime} 30^{\prime \prime}$.

The distribution of the provisioning and non-provisioning flights during the day (Fig. 1) indicate that only in the late evening (17.00-18.59) are there more non-provisioning than provisioning flights. There is no linear correlation between the number of both types of flights and air temperature (average per hour) (Spearman correlation test; $r_{\text {(provisioning) }}=-0.036, \mathrm{r}_{\text {(non- }}$ provisioning) $=0.436 ; \mathrm{n}=11 ; \mathrm{P}_{\text {(provisioning) }}=0.458, \mathrm{P}_{\text {(non-provisioning) }}=$ $0.090, \mathrm{~ns})$. No significant correlation was found between width of a wasp's head and the hour of the first daily return to the nest with prey (Spearman correlation test; $\mathrm{r}=0.16, \mathrm{n}=54, \mathrm{P}=0.23$, ns).

Excluding the last flight of the day, the entrance of a nest was usually left open between sequential flights $(92.2 \%, \mathrm{n}=3157)$, otherwise a female closed herself inside the nest. Nest-closure was preceded by return with prey in $36 \%$ of the cases, by return without prey in $22 \%$, and after attempts at nest usurpation in $42 \%(\mathrm{n}=245)$.

The last flight of the day is always followed by nest closure; during the day nest-closure occurred significantly more often in late afternoon (Spearman correlation test; $\mathrm{r}=0.964 ; \mathrm{n}=11 ; \mathrm{P}=$ $0.00013,<0.001$ ). Duration of nest-closure (until no more ground movements were visible) lasted from 1 to $150 \mathrm{~min}$, with in $74 \%$ lasting from 1 to $10 \mathrm{~min}$. 


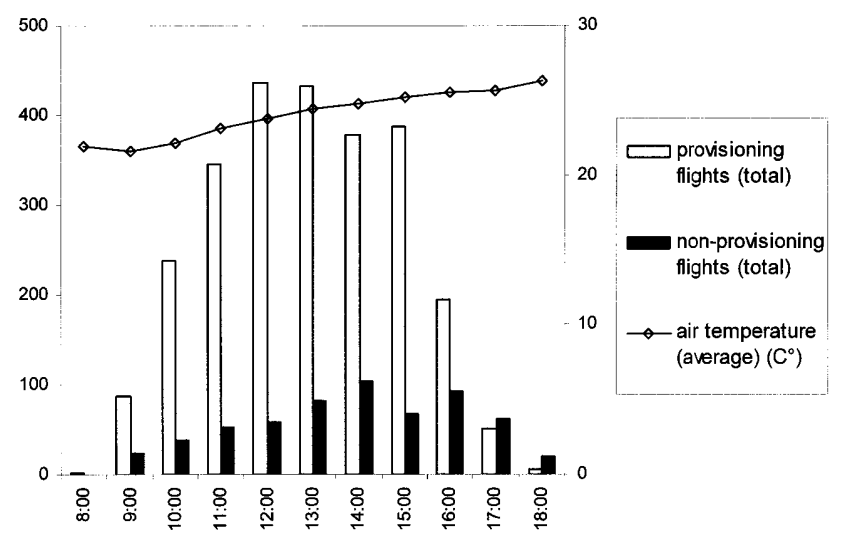

Fig. 1. Number of provisioning and non-provisioning flights and average air temperature each hour from 8.00 to 18.00 (1997); left ordinate axis: total number of flights; right ordinate axis: average temperature.

Dissections of 6 C. arenaria nests showed that complete cells contain from five to more than 10 paralysed weevils. The average number of prey brought to a nest, calculated for the whole period of the study (except rainy days), was of 2.05 per day per wasp (range $=0-4.53 ; \mathrm{SD}=1.08 ; \mathrm{n}=34$ ). The stinging of the prey occurred far from the nest, probably on plants where the weevils live, but sometimes re-stinging of prey was observed before nest entering. In most cases (12 out of 14) restinging happened when the wasp found her nest closed and an usurper female inside it.

Wasps transported their prey in flight, by means of their mandibles (grasping the pro-mesothorax junction of the prey) and middle legs, but in 5 out of 2211 cases they carried very small prey only in their mandibles. Weevils were held horizontally, venter down, head facing forward.

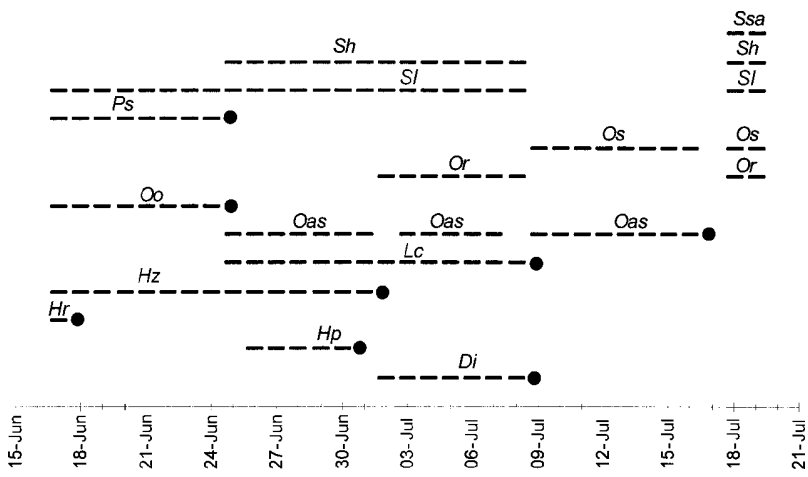

Fig. 2. Presence/absence of prey species during the period $15^{\text {th }}$ June-2 $1^{\text {st }}$ July, 1997-1999. Codes for prey species: $D i=$ Donus intermedius (Boheman); Hp = Hypera postica (Gyllenhal) [=variabilis (Herbst)]; $\mathrm{Hr}=$ Hypera rumicis (L.); $\mathrm{Hz}=$ Hypera zoilus (Scopoli); Lc = Lepyrus capucinus (Schaller); Oas $=$ Otiorhynchus apenninus Stierlin ssp. salicicola Heyden; Oo $=$ Otiorhynchus ovatus $(\mathrm{L}$.); Or = Otiorhynchus rugosostriatus (Goeze); Os = Otiorhynchus sulcatus (F.); Ps = Polydrusus sericeus (Schaller); $\mathrm{Sl}=$ Sitona lepidus Gyllenhal [=flavescens (Marsham) nom. praeocc.]; Sh = Sitona hispidulus (F.); Ssa = Sitona sulcifrons (Thunberg) ssp. argutulus Gyllenhal. Black circles mark the last date of collection of a species, when they were not found later on during the observation period.

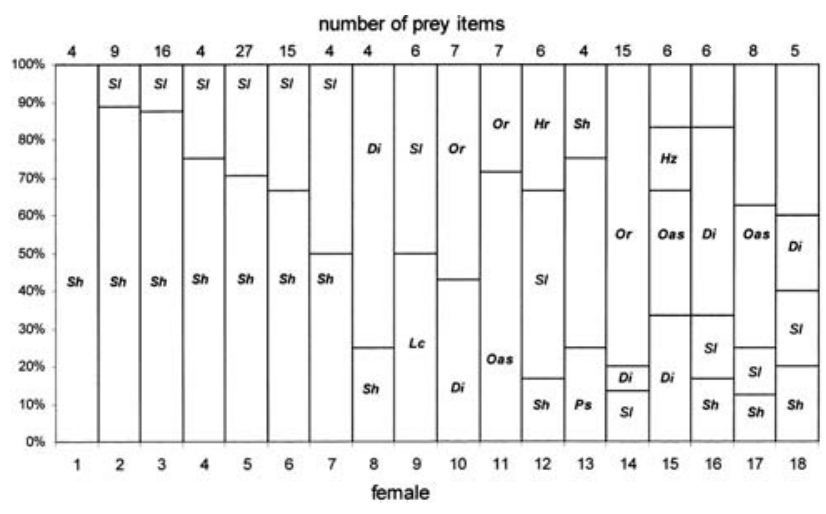

Fig. 3. Composition of the prey (as percentage of individuals per species) of 18 Cerceris arenaria females (1999). Codes for prey species as in the legend of Fig. 2.

\section{Prey selection}

The 13 most abundant of the 20 species recorded as prey belong to the genera Sitona (52\%) and Otiorhynchus (35\%) and mostly to the subfamilies Brachyderinae and Hyperinae (both represented by 6 species). Some of the prey collected from wasps returning to their nests (in 1997-1999) were recorded for only a short period (1 day for Hypera rumicis, 2 days for Sitona sulcifrons argutulus, 5 days for Hypera postica). Other species were collected, overall or most of the period of study (e.g. Otiorhynchus apenninus salicicola, Sitona hispidulus, Sitona lepidus) (Fig. 2).

From 18 marked wasps, more than 3 prey specimens (up to 27) were collected (Fig. 3). For 11 of these wasps, the prey belonged only to one or two species. Moreover, for 7 wasps (out of 18), all prey items were Sitona species. In order to obtain reliable results, the analysis was restricted to the most abundant prey $(S h=$ Sitona hispidulus $)$ relative to all other prey, and to the five females (Fig. 3) which each collected 9 or more prey items. Observed were compared with expected results using a $5 \times 2$ Contingency Table of the number of Sh prey and total number of prey collected by each wasp. This indicates that those wasps collected proportionally more Sh prey than expected $\left(\chi^{2}=\right.$ $32.65, \operatorname{dgf}=4, \mathrm{P}<0.005)$.

The sizes of the wasps (head width, ranging from 2.60 to 4.20 $\mathrm{mm}$ ) and that of their prey (pro-mesothorax junction width, ranging from 0.71 to $2.70 \mathrm{~mm}$ ) were linearly correlated (Pearson Test, $\mathrm{r}=0.65 ; \mathrm{n}=85 ; \mathrm{P}=3.64^{-12},<0.001$ ).

Comparing the number of prey collected (Table 1), the average number of provisioning flights per day (per wasp) was significantly higher for a wasp hunting "small" than "large" prey (see Methods for definitions): 3.83 (range $=1.0-11.2$, SD $=2.07$ ) against 1.96 (range $=1.0-4.5, \mathrm{SD}=0.83$ ) (MannWhitney test, $\mathrm{U}=183.5, \mathrm{n}_{\text {small }}=55, \mathrm{n}_{\text {large }}=17, \mathrm{P}=0.00015$, $<0.001)$. The average time spent in provisioning flights was significantly shorter for "small" than for "large" prey: 49'20" (range $=14^{\prime} 26^{\prime \prime}-4 \mathrm{~h} 06^{\prime} 47^{\prime \prime}, \mathrm{SD}=34^{\prime} 04^{\prime \prime}$ ) against 1 h $05^{\prime} 30^{\prime \prime}$ (range $=30^{\prime} 12^{\prime \prime}-2$ h $38^{\prime} 34^{\prime \prime}, \mathrm{SD}=34^{\prime} 48^{\prime \prime}$ ) (Mann-Whitney test, $\left.\mathrm{U}=307, \mathrm{n}_{\text {small }}=55, \mathrm{n}_{\text {large }}=17, \mathrm{P}=0.033,<0.05\right)$.

Comparing the different hunting wasps (Table 1), the size of the wasps that hunted "large" and "mixed" ("small" + "large") prey was larger than that of those that hunted "small" prey (Mann-Whitney test: $\mathrm{U}=38 ; \mathrm{n}_{\text {large }}=14, \mathrm{n}_{\text {small }}=40 ; \mathrm{P}=1.36^{-6}$, $\left.<0.001 ; \mathrm{U}=171.5 ; \mathrm{n}_{\text {mixed }}=33, \mathrm{n}_{\text {small }}=40 ; \mathrm{P}=4.43^{-8}<0.001\right)$. There was no difference in the size of the wasps hunting "large" and "mixed" prey (Mann-Whitney test; $\mathrm{U}=261.5 ; \mathrm{n}_{\text {mixed }}=33$, $\left.\mathrm{n}_{\text {large }}=14 ; \mathrm{P}=0.46, \mathrm{~ns}\right)$. 
TABLE 1. Characteristics of the wasps hunting for prey of different size. The female wasps were observed for at least 3 days. See text for explanation of terms.

\begin{tabular}{|c|c|c|c|c|c|c|}
\hline & \multicolumn{6}{|c|}{ wasps hunting for } \\
\hline & \multicolumn{2}{|c|}{ "small" prey } & \multicolumn{2}{|c|}{ "large" prey } & \multicolumn{2}{|c|}{ "mixed" prey } \\
\hline & average & SD & average & SD & average & SD \\
\hline number of prey per day & 3.83 & 2.07 & 1.96 & 0.83 & 2.93 & 1.54 \\
\hline wasp size & 3.29 & 0.33 & 3.89 & 0.22 & 3.81 & 0.29 \\
\hline "biomass" of prey per day & 3.24 & 1.69 & 27.97 & 10.27 & 14.38 & 9.78 \\
\hline wasp "biomass" & 36.76 & 10.78 & 59.53 & 10.02 & 56.36 & 12.75 \\
\hline frequency $(n=133)$ & \multicolumn{2}{|c|}{$41 \%$} & \multicolumn{2}{|c|}{$13 \%$} & \multicolumn{2}{|c|}{$46 \%$} \\
\hline
\end{tabular}

Wasp size $=$ head width $(\mathrm{mm})$; prey "biomass" $=(\text { pro-mesothorax junction width })^{3}\left(\mathrm{~mm}^{3}\right)$; wasp "biomass" $=(\text { head width })^{3}\left(\mathrm{~mm}^{3}\right)$.

The biomass of prey was based on the average of the range of the pro-mesothorax junction widths of the different kinds of prey: $0.95 \mathrm{~mm}$ for "small", $1.6 \mathrm{~mm}$ for "medium" and $2.35 \mathrm{~mm}$ for "large" prey. For the marked wasps, it was the width of their head. The cubic power of these linear dimensions should be roughly proportional to the corresponding (prey or wasp) biomass. The average daily "biomass" of captured prey, divided by the "biomass" of the wasp, increased with wasp "biomass" (Spearman correlation test; $\mathrm{n}=87 ; \mathrm{r}=0.31 ; \mathrm{P}=0.0039,<0.01$ ).

\section{DISCUSSION}

The results show that females spent most of their time away from their nests $(57 \%, \mathrm{n}=1378 \mathrm{~h})$ foraging. This is the case in almost all species of solitary wasps that do not close their nests between provisioning flights (Bohart \& Menke, 1976).

The foraging activity of $C$. arenaria, measured as number of provisioning flights per hour, was affected by rain, as is the case of many other solitary wasps (e.g. Evans, 1966), but not by air temperature. Nests are generally left open between flights. The wasps only close their nests (from the inside): (1) the most frequent case, after the last flight of the day; (2) when it rains, which induces an immediate return to the nest; (3) probably when excavating a new cell or laying an egg; (4) as a response to a nest usurpation attempt by another female. Nest usurpation is very common in this species (Field \& Foster, 1995) and is possibly the only way to obtain a new nest (Polidori et al., in prep.). (1) occurs at the end of a day, (2)-(4) at any time of day.

Considering that a wasp collects, on average, 2 prey per day, and we found ca. 5-10 prey in a cell, it takes $2-5$ days to provision a cell. In addition, as a nest is, on average, provisioned for ca. 21 days (by an average of 5.33 wasps) (Polidori et al., in prep.), the number of cells per nest should be $4-10$. These values, as well as the number of prey per cell agree with those found by Willmer (1985) for the same species (ca. 8 prey per cell and 5-11 cells per nest). Since the mean number of nestclosures per nest, during the whole season is $2.28(\mathrm{SD}=2.72$; range $=0-12 ; n=80$ ) (excluding those after the last trip of the day), the construction of new cells (and laying of eggs) occurred mostly in the late evening, after the last return to the nest.

The way in which the prey was transported is similar to that observed in other species of Cerceris (Evans, 1962; Genaro \& Sanchez, 1993).

In spite of an extensive search the weevils collected by the wasps were not found. C. arenaria evidently looks for weevils in places not easily accessible to man, such as in the canopy of trees. At least some C. arenaria individuals, appear to have statistically significant preference for a particular species of prey. This may not necessarily involve true selection, but only a fidelity for particular hunting places where a particular prey species is abundant. This is the case, for example, in some generalist beewolves (Philanthus spp.), whose females develop temporary fidelities to particular sites, but not to particular taxa of prey (Stubblefield et al., 1993). Hamm \& Richards (1930) also observed that some females of $C$. arenaria hunted one genus of weevil and others different one. They suggest that individuals have preferences for hunting sites (different kinds of plants) even though they collected only two genera of weevils [Curculio (= Balaninus) and Strophosomus] $(\mathrm{n}=366$ individuals), while Polidori et al. (in prep.) recorded 8 genera $(n=1133$ individuals).

There is a linear and positive correlation between the size of the wasps and that of their prey. Size might determine, at least in part, prey selection. This is particularly so for smaller wasps, which can not carry large prey. This is the case for Cerceris californica Cresson (Linsley \& MacSwain, 1956), and other sphecoid wasps (e.g. Gwynne \& Dodson, 1983).

That it is the smallest wasp that hunt "small" prey and make the most provisioning flights per day does not accord with Willmer (1985), who states the larger females usually make more (and with shorter duration) successful provisioning trips per day than the smaller females. Willmer suggests that the effects of temperature account for the difference between the activity of large and small females, but the effect would vary strongly depending on its daily distribution. The lowest average air temperature recorded in our study $\left(22^{\circ} \mathrm{C}\right.$ ca. $)$ was higher than that recorded by Willmer $\left(16^{\circ} \mathrm{C} \mathrm{ca}\right.$.). On the other hand, the highest mean temperature, was similar in the two studies (around $26-27^{\circ} \mathrm{C}$ ), and occurred at 18.00 in our study but earlier (between 14.00 and 16.00) in Willmer's. The difference in temperature in the two studies could be the reason why Willmer found that larger females started provisioning earlier than smaller females.

The inverse relationship observed between the number of provisioning flights and the size of the prey agrees with the fact that every wasp should provide each of her larvae with more or less the same quantity of food (biomass). Interesting implications follows from the fact that the size of a wasp determines the range of prey hunted. In this study, $C$. arenaria varied greatly in size. Since the smallest wasps had the smallest range of species of prey, any progressive bias to a smaller average size (due to factors such as selective parasitism of the larger females) would lead to a progressive reduction in the range of prey, which would result in increasing competition for prey between females and a reduction in colony stability (due to a reduction in the reproductive success of the competing females). Moreover, in this species, intraspecific parasitism consists only of nest usurpation (Field, 1992; Field \& Foster, 1995; Polidori et al., in prep.), not in kleptoparasitism, so a non-hunting wasp can not obtain prey from usurped conspecifics. Thus, preserving a high size range in the population may be a way of reducing competition for prey. This hypothesis, which operates at the level of a population, is similar to the hypothesis proposed to explain the 
co-existence of many sympatric species of Cerceris (Scullen \& Wold, 1969; Stubblefield et al., 1993).

The significant positive correlation between prey (divided by wasp biomass) and wasp biomass does not favour size stability as the larger prey biomass collected by larger wasps could produce still larger wasps (or a greater number of wasps). However, other factors could be important in determining population size range of the wasp. Reducing the time spent provisioning reduces the risk of nest usurpation. This would favour the smaller wasps. On the other hand, larger wasps seem to be at an advantage when displacing the owner wasp in usurpation attempts (Polidori et al., in prep.).

In terms of their possible use in a biological pest control the following data on their hunting efficiency maybe of interest. In 1999, 907 nests were recorded (Polidori et al., in prep.). Each nest may be used, on the average, for 20.73 days during the season (Polidori et al., in prep.) and each wasp collected an average 2.05 prey per day, i.e. approximately 40,000 weevils could be destroyed in the study area during the whole season.

AKNOWLEDGEMENTS. Thanks are extended to A. Bianchi for the logistic support, B. Valarani for the help in collecting field data; G. Pagliano for determination of Hymenoptera and C. Pesarini (Museo Civico di Storia Naturale di Milano) and F. Francia for their very kind professional help. Part of the present work was supported by a three years grant FIRB (Fondo per gli Investimenti della Ricerca di Base) RBAU019H94-001 (2001).

\section{REFERENCES}

Alcock J. 1975: Social interactions in the solitary wasp Cerceris simplex (Hymenoptera: Sphecidae). Behaviour 54: 142-152, pl. V.

Bohart R.M. \& Menke A.S. 1976: Sphecid Wasps of the World. A Generic Revision. University of California Press, Berkeley, Los Angeles, London, IX +695 pp., 1 color plate.

Byron A.A. \& Asís J.D. 1997: Patterns of nest occupancy and nest provisioning in Cerceris rufopicta Smith (Hymenoptera: Sphecidae). J. Insect Behav. 10: 871-893.

Evans H.E. 1962: The evolution of prey-carrying mechanisms in wasps. Evolution 16: 468-483.

Evans H.E. 1966: The behavior patterns of solitary wasps. Annu. Rev. Entomol. 11: 123-154.

Evans H.E. 1971: Observations on the nesting behaviour of wasps of the tribe Cercerini. J. Kans. Entomol. Soc. 44: 500-523.

FIELD J. 1992: Intraspecific parasitism as an alternative reproductive tactic in nest-building wasps and bees. Biol. Rev. 67: 79-126.
Field J. \& Foster W.A. 1995: Nest co-occupation in digger wasp Cerceris arenaria: co-operation or usurpation? Anim. Behav. 50: 99-112.

Frank J.H. \& BenNet F.D. 1995: Larra bicolor (Hymenoptera: Sphecidae), a biological control agent of Scapteriscus mole crickets (Orthoptera: Gryllotalpidae), established in northern Florida. Fla Entomol. 78: 619-623.

Genaro J.A. \& Sanchez C.S. 1993: Conduca de nidificación de Cerceris cerverae, C. cubensis y C. festiva en Cuba (Hymenoptera: Sphecidae). Carib. J. Sci. 29: 39-43.

Gulmahamad H. 1997: Super sleuth. Pest Contr. Technol. 25: $44-50$.

GwynNe D.T. \& Dodson G.N. 1983: Nonrandom provisioning by the digger wasp, Palmodes laeviventris (Hymenoptera: Sphecidae). Ann. Entomol. Soc. Am. 76: 434-436.

Hamm A.H. \& Richards O.W. 1930: The biology of the British fossorial wasps of the families Mellinidae, Gorytidae, Philanthidae, Oxybelidae, and Trypoxylidae. Trans. Entomol. Soc. Lond. 78: 95-131.

Lecoq M. \& Pierozzi I. JR. 1995: Attaques de Prionyx thomae (Fabricius, 1775) (Hymenoptera, Sphecidae) sur un criquet ravageur, Rhammatocerus schistocercoides (Rehn, 1906), au Brésil (Orthoptera, Acrididae). Bull. Soc. Entomol. Fr. 100: 515-520.

LinSLEY E.G. \& MACSwain J.W. 1956: Some observations on the nesting habits and prey of Cerceris californica Cresson (Hymenoptera, Sphecidae). Ann. Entomol. Soc. Am. 49: 71-84.

McCorquodale D.B. 1989: Soil softness, nest initiation and nest sharing in the wasp, Cerceris antipodes (Hymenoptera: Sphecidae). Ecol. Entomol. 14: 191-196.

Salbert H.A. \& Elliot N. 1979: Observations on the nesting behaviour of Cerceris waltingensis (Hymenoptera, Sphecidae, Philanthinae). Ann. Entomol. Soc. Am. 72: 591-595.

Scullen H.A. \& Wold J.L. 1969: Biology of wasps of the tribe Cercerini, with a list of the Coleoptera used as prey. Ann. Entomol. Soc. Am. 62: 209-214.

Stubblefield J.W., Seger J., Wenzel W. \& Heisler M.M. 1993: Temporal, spatial, sex-ratio and body-size heterogeneity of prey species taken by the beewolf Philanthus sanbornii (Hymenoptera: Sphecidae). Phil. Trans. R. Soc. Lond. (B) 339: 397-423.

WILLMER P.G. 1985: Size effects on hygrotermal balance on the foraging patterns of a sphecid wasp, Cerceris arenaria. Ecol. Entomol. 10: 469-479.

Received April 4, 2004; revised and accepted February 7, 2005 